\title{
ASSESSMENT OF INSTRUCTIONAL FACILITIES IN IMPLEMENTING THE CONTENTS OF THE MOTOR VEHICLE MECHANICS' WORK CURRICULUM IN TECHNICAL COLLEGES IN NORTH CENTRAL NIGERIA
}

\author{
${ }^{1}$ Ogbuanya, T. C. and ${ }^{2}$ Usman, D. A. \\ ${ }^{1}$ Industrial and Technical Education Department, University of Nigeria, Nsukka, Nigeria; \\ ${ }^{2}$ Federal Government Girls' College, Bwari, Abuja, Nigeria \\ Email: usmandavid007@gmail.com
}

\begin{abstract}
The training of motor vehicle mechanics is not only expertise demanding, but also requires a lot of facilities which has to be effectively utilized for the realization of instructional objectives. The objectives of the study were (1) to ascertain the availability of instructional facilities; and (2) to find out the extent of the usage of the instructional facilities in implementing the contents of the MVMWC. The population of the study was 465; consisting of 418 male and 38 female MVMW National Technical Certificate (NTC) III graduating students for the 2017/2018 session, in the 22 accredited technical colleges in the North-Central States of Nigeria, and 9 MVMW graduates of technical colleges in the area of study who were operating functional workshops. The study adopted a Multi-stage Sampling Technique to select a sample size of 189 which comprised 165 male and 15 female MVMW NTC III graduating students and 9 MVMW graduates of technical colleges from the area of the study. A questionnaire and Focus Group Discussion (FGD) were used as instruments for data collection. The research questions were analyzed using mean, frequency count, and percentages. The findings of this study revealed: lack of basic instructional facilities for effective implementation of the MVMWC in technical colleges in the North Central States of Nigeria; and a low extent of utilization of the very few instructional facilities available.
\end{abstract}

Keywords: assessment, availability, instructional facilities, technical colleges, utilization

\section{INTRODUCTION}

As prime movers of people and goods, automobiles contribute daily to economic and social systems. The automobile, commonly known as a motor vehicle or car, is a composite of many complex systems with a sophisticated group of technologies assembled. Malone [1] stated that today's cars are factory equipped with computer systems that have more intelligence than the United States' National Aeronautic and Space Administration (NASA) spacecraft sent to the moon. Automobiles now use sophisticated computer technology, advanced wiring, intricate circuitry, and complex engineering [2]. The automobile today is controlled by various electronic sensors, actuators, circuits, and computers [3]. Electronics control is approximately 75 percent of modern automobile's operation [4]. Today's car is a rolling computer; as there are 30 to 100 microprocessors in a car controlling various systems. These systems require routine diagnosis, maintenance, and service [5]. The maintenance of the numerous subsystems of modern automobiles has become highly challenging and expertise demanding.

The automobile maintenance personnel, commonly known as motor vehicle mechanics, must therefore be equipped with the relevant knowledge, skills, and the right attitude for effective maintenance of modern automobiles, owing to the influx of automobiles into Nigeria and the challenges of maintaining them. Today's motor vehicle mechanic is expected to diagnose, service, and completely repair any problem in the automobile. He/she must be specially trained and equipped for on-board 
diagnostic (OBD-2) technology to avoid potential errors in diagnosing car trouble codes and making appropriate repairs [1]. The motor vehicle mechanic faces the challenges of understanding each of the systems found in the automobile and the interrelationship of these systems, as well as, the need to stay current with changes as new models appear every year [3]. They must understand not only the parts, nomenclature, and operation, but also understand the diagnosis and service procedure for each system in the vehicle. United States Bureau of Labor Statistics (USBLS) [6] stated that motor vehicle mechanics must have an increasingly broad knowledge of how vehicles' complex components work and interact. They also must be able to work with electronic diagnostic equipment and digital manuals and reference materials. Motor vehicle mechanics also need to have: an interest in mechanical/electronic systems in a motor vehicle, good problem-solving ability, good vision, hearing and sense of smell, manual dexterity, and mechanical aptitude, ability to communicate well in English, physical fitness, and strength, ability to drive a range of vehicles, ability to read technical diagrams and illustration, have concern for safety and responsible work attitude; and in keeping up to date with technology [7]. The above requirements, therefore, not only make the training of motor vehicle mechanics highly tasking and expertise demanding, but also require a very rich curriculum with a lot of facilities for effective and efficient implementation. Motor Vehicle Mechanics' Work Curriculum (MVMWC), in this study, is the program in use for training motor vehicle mechanics in the Nigerian formal school system for the maintenance of all types of vehicles.

The components of the Motor Vehicle Mechanics Work Curriculum (MVMWC) include aim, objectives, contents, teaching strategies, instructional facilities, and method of evaluation. The availability of the appropriate instructional facilities, as well as the effective utilization of the instructional facilities, are not only imperative to the realization of the objectives of the program but are also the determinant of the success and otherwise of the program.

Instructional facilities are vital in the teaching and learning process. One major index for measuring the successful implementation of any curriculum is the provision and management of the facilities available for such programs [8]. It is a very good means of measuring the standard and quality of the education to be provided, Nzekwe stressed. Instructional facilities are specifically meant for direct teaching and learning. They include classrooms, classroom seats, workshops, laboratories, internet facilities, libraries, equipment, chalkboard, audio-visual learning equipment, among others [9]. These facilities bear directly on the teaching-learning process. They enable the teacher to carry out his/her work well and also help the learners to learn effectively [10]; therefore, they are an integral component of the conditions of learning. The instructional facilities offer the reality of experience, provide visual aspects to a process or technique, facilitate the understanding of abstract concepts, and provide the opportunity for the learner to manipulate [8]. In this study, instructional facilities are those things that enable teachers/instructors to carry out their work well and also help trainees to learn (acquire skills, knowledge, and attitude) effectively for the achievement of the aim and objectives of MVMWC. Anike $\&$ Tari [10] posited that, the quality of training that trainees get bears on direct relevance to the availability or the lack of physical facilities and overall atmosphere 
where the learning takes place. According to the Nigerian Educational Research and Development Council (NERDC) [11], the MVMW program is inherently workshopbased; and therefore, calls for an adequately equipped automobile workshop in each school that offers the course. This was reiterated in the National Board for Technical Education [12] guidelines and procedures for the establishment of private technical and technological institutions in Nigeria that, an adequately equipped workshop for the specific modules to be taught in technical colleges must be on the ground as criteria for accrediting any technical college program. However, researches show that students' potentials are not properly channeled as schools lack basic instructional facilities necessary for effective curriculum implementation [13], [14]. In addition to the adequate availability of instructional facilities, effective utilization of the instructional facilities is imperative; because it is one thing to have the facilities, and another thing entirely to (be able to) use them.

The availability and effective utilization of instructional facilities, in addition to the quality of curriculum implementation of any society, is the bedrock of its political, economic, scientific, and technological well-being.

The education system in northern Nigeria is facing a lot of challenges. The implementation of the MVMWC in the North Central States of Nigeria is also factored in the situation, as graduates of technical colleges in Plateau State, a case study carried out by Nyapson [16], have irrelevant and inadequate skills in motor vehicle mechanic, which has rendered most of them jobless in the society. Nyapson stated that they neither set up their workshops nor are they being employed by automobile industries in the state. Jika [17] posited that such half-baked auto craftsmen in the society often cause more damages on vehicles than repairs when contracted to work on them; and many serviced/repaired vehicles by these craftsmen, according to Jika, have sent many people to their early deaths due to inaccurate or faulty work they've performed on them. Regrettably, lack of instructional facilities, coupled with the ineffective utilization of the few available, in the implementation of the MVMWC in technical colleges in North Central states of Nigeria has been the major bane of the program; as graduates of the program lacked the basic skills and the right attitude needed for gainful employment in today's automobile industry. Therefore, the problem of this study was to assess the availability and utilization of instructional facilities in implementing the MVMWC in technical colleges in the North Central states of Nigeria.

Today's automobile is a composite of many complex systems with a sophisticated group of technologies assembled. Today's motor vehicle mechanic is expected to diagnose, service, and completely repair any problem on the automobile. Furthermore, the mechanic must possess good problemsolving ability, manual dexterity and mechanical aptitude, responsible work attitude; and keeping up to date with technology. The above requirements can only be achieved via a rich curriculum with a lot of facilities for effective implementation.

Unfortunately, several studies [7], [18]-[21] have revealed that technical college products of the MVMW program lacked the basic skills needed for gainful employment in today's automobile industry. Regrettably, lack of instructional facilities, coupled with the ineffective utilization of the few available, in the implementation of the MVMWC in technical colleges in North Central states of Nigeria has been the major 
bane of the program; as graduates of the program lacked the basic skills and the right attitude for gainful employment in today's automobile industry. Therefore, the problem of this study was to assess the availability and utilization of the instructional facilities in implementing the MVMWC contents in technical colleges in North Central Nigeria.

\section{METHOD}

The study adopted a descriptive survey research design. The study was carried out in North-Central Nigeria; comprising of Kogi, Niger, Benue, Kwara, Plateau, Nassarawa, and the Federal Capital Territory. The population for this study was 465 ; consisting of 418 male and 38 female MVMW NTC III graduating students for the 2017/2018 session in the 22 accredited technical colleges in the North-Central Zone of Nigeria, and 9 MVMW graduates who were operating functional workshops. The study adopted the Multi-stage Sampling Technique. The subjects for the study comprised two sample groups - graduating students and graduates of MVMW. A sample size of 189 was used for the study, comprising of 165 male and 15 female MVMW NTC III graduating students, and 9 MVMW graduates who were operating functional workshops. In stage one, a purposive sampling technique was adopted to select (based on school type) two Federal Science and Technical Colleges and six State-owned Technical Colleges. In stage two, a proportionate stratified random sampling technique was adopted to sample the 165 male and 15 female MVMW NTC III graduating students from the selected schools representing a ratio of 11:1 based on the proportion of the population of male and female. Some 9 other MVMW graduates who were operating functional workshops in the area of the study were also selected for Focus Group Discussion (FGD).

The study utilized both quantitative and qualitative techniques to enrich the findings. The following instruments were used for data collection: For Research Question one (RQ1), a Checklist of instructional facilities available, containing 91 items based on the specified minimum number of tools and equipment required by NBTE for implementation of the MVMWC was used; and the response categories for the checklist were: $\mathrm{A}=$ Available, $\mathrm{BHANR}=$ Below Half of Average Number Required, and NA = Not Available, respectively. For Research Question two (RQ 2), a Questionnaire titled: the Extent of the Usage of the Instructional Facilities Available in Implementing the Contents of the MVMWC was used; with response categories of Very Great Extent (VGE), Great Extent (GE), Moderate Extent (ME) Low Extent (LE) and Lowest Extent (LSE) rated 5, 4, 3, 2, and1 respectively. Cronbach Alpha $(\alpha)$ reliability technique was used to establish the internal consistency of the instrument. The reliability coefficient for the instrument was 0.77

The Focus Group Discussion (FGD) was conducted with nine graduates of technical colleges in the area of the study who were operating functional workshops. This was to find out from them, based on their experience on the job after school and the tools and equipment used on the job after leaving school; the quantity and quality of the tools and equipment that were available and effectively utilized during their school program in training them; and comparing them with those of the workplace.

Questionnaires were administered to the respondents by the researcher through personal contact and with the help of MVMW teachers from each of the sampled schools, 
who served as research assistants. The adequate copies of each instrument were administered accordingly and retrieved from the respondents for analysis. Thereafter, the nine graduates selected in the area of the study who were operating functional workshops were assembled in a designated location, and the focus group discussion was conducted.

Data collected were subjected to appropriate quantitative and qualitative analyses using descriptive statistics. The research questions were analyzed using mean, frequency count, and percentages. Research question 1 was analyzed using frequency counts and percentages, while mean was used in analyzing research question 2.

\section{RESULTS AND DISCUSSION}

The instructional facilities available, for implementing the curriculum contents of the MVMWC in technical colleges in North Central Nigeria are presented in Table 1.

Table 1. Frequency and Percentage of Instructional Facilities Available for Implementing the MVMWC Contents in Technical Colleges in North Central Nigeria

\begin{tabular}{|c|c|c|c|c|c|c|}
\hline SN & $\begin{array}{l}\text { Tools and Equipment Required by NBTE } \\
\text { for Implementing MVMWC Contents in } \\
\text { Nigeria's Technical Colleges }\end{array}$ & $\begin{array}{l}\text { Minimum } \\
\text { Number } \\
\text { Required in } \\
\text { Each } \\
\text { Technical } \\
\text { College }\end{array}$ & $\begin{array}{c}\text { Total } \\
\text { Minimum } \\
\text { Number } \\
\text { Required in } \\
\text { Sampled } \\
\text { Technical } \\
\text { Colleges }\end{array}$ & $\begin{array}{c}\text { Total } \\
\text { Number } \\
\text { Available in } \\
\text { Sampled } \\
\text { Technical } \\
\text { Colleges }\end{array}$ & $\%$ & Remark \\
\hline 1 & $\begin{array}{l}\text { Toolboxes (comprising a set of flat, ring, } \\
\text { half-round, and triangular files) }\end{array}$ & 10 & 80 & 21 & 26.25 & BHAMNR \\
\hline 2 & Ball pein hammer & 10 & 80 & 24 & 30.00 & BHAMNR \\
\hline 3 & Hacksaws with extra blades & 10 & 80 & 27 & 33.75 & BHAMNR \\
\hline 4 & $\begin{array}{l}300 \mathrm{~mm} \text { engineer rule socket spanners sets, } \\
\text { with extension }\end{array}$ & 10 & 80 & 23 & 28.75 & BHAMNR \\
\hline 5 & (6-32) open and flat spanners & 10 sets & 80 & 21 & 26.25 & BHAMNR \\
\hline 6 & Ring spanners $(6-32 \mathrm{~mm})$ & 10 sets & 80 & 20 & 25.00 & BHAMNR \\
\hline 7 & Energy stone/block cloth & 10 & 80 & 0 & 0 & NA \\
\hline 8 & Plug spanners & 10 & 80 & 17 & 21.25 & BHAMNR \\
\hline 9 & Magnet spanners & 10 & 80 & 16 & 20.00 & BHAMNR \\
\hline 10 & Allen keys & 10 & 80 & 19 & 23.75 & BHAMNR \\
\hline 11 & Feeler gauges & 10 & 80 & 17 & 21.25 & BHAMNR \\
\hline 12 & Oil cans & 10 & 80 & 23 & 28.75 & BHAMNR \\
\hline 13 & Grease guns & 10 & 80 & 14 & 17.75 & BHAMNR \\
\hline 14 & Spark plug files & 10 & 80 & 6 & 7.5 & BHAMNR \\
\hline 15 & Combination pliers & 10 & 80 & 22 & 27.50 & BHAMNR \\
\hline 16 & Longnose pliers & 10 & 80 & 21 & 26.25 & BHAMNR \\
\hline 17 & Wirecutter & 10 & 80 & 11 & 13.75 & BHAMNR \\
\hline \multirow[t]{2}{*}{18} & Tyre pressure gauges & 10 & 80 & 6 & 7.50 & BHAMNR \\
\hline & DRILLING AND SCREW CUTTING & & & & & \\
\hline 19 & Electric Hand Drill & 2 & 16 & 4 & 25.00 & BHAMNR \\
\hline 20 & Drill bits & 3 sets & 24 sets & 9 sets & 37.50 & BHAMNR \\
\hline 21 & $\begin{array}{l}\text { Set of stock and dies - UNC, UNF, and } \\
\text { metric }\end{array}$ & 2 sets & 16 sets & 2 sets & 12.50 & BHAMNR \\
\hline 22 & $\begin{array}{l}\text { Taps and wrenches - UNC, UNF, and } \\
\text { metric }\end{array}$ & 2 sets & 16 sets & 2 sets & 12.50 & BHAMNR \\
\hline 23 & Thread file & 2 & 16 & 3 & 18.75 & BHAMNR \\
\hline 24 & Roller type thread restorer & 2 & 16 & 1 & 12.50 & BHAMNR \\
\hline 25 & Screw (stud) extractor set & 2 & 16 & 2 & 12.50 & BHAMNR \\
\hline
\end{tabular}




\begin{tabular}{|c|c|c|c|c|c|c|}
\hline & MEASURING TOOLS & & & & & \\
\hline 26 & Vernier caliper & 15 & 120 & 22 & 18.33 & BHAMNR \\
\hline 27 & Hand gloves/apron & 5 & 40 & 12 & 30 & BHAMNR \\
\hline 28 & Surface plates & 2 & 16 & 6 & 37.50 & BHAMNR \\
\hline 29 & Vee blocks & 8 & 64 & 16 & 25.00 & BHAMNR \\
\hline 30 & $\begin{array}{l}\text { Micrometer } 0.25 \mathrm{~mm}, 25-50 \mathrm{~mm}, 50-75 \mathrm{~mm} \\
\text { internal and external }\end{array}$ & 3 each & 24 each & 10 & 41.67 & BHAMNR \\
\hline \multirow[t]{2}{*}{31} & Dial gauge indicator with magnetic stand & 2 & 16 & 4 & 25.00 & BHAMNR \\
\hline & MACHINE TOOLS & & & & & \\
\hline 32 & Grinding machines with assorted wheels & 1 & 8 & 2 & 25.00 & BHAMNR \\
\hline 33 & A bench grinder with wheels & 1 & 8 & 3 & 37.50 & BHAMNR \\
\hline 34 & Workshop surface gauges & 15 & 120 & 8 & 6.67 & BHAMNR \\
\hline 35 & Valve grinding machine & 1 & 8 & 2 & 25.00 & BHAMNR \\
\hline 36 & Blow lamps & 5 & 40 & 6 & 15.00 & BHAMNR \\
\hline 37 & $\begin{array}{l}\text { Soldering iron } \\
\text { LUBRICATION BAY/TYRE AND } \\
\text { WHEEL SERVICE }\end{array}$ & 5 & 40 & 6 & 15.00 & BHAMNR \\
\hline 38 & $\begin{array}{l}\text { Compressor ( } 3 \text { phase motor-driven type } \\
\text { complete with a spray gun, grease, hose) }\end{array}$ & 1 & 8 & 0 & 0 & NA \\
\hline 39 & Wheel balance (rim 13-15) & 1 & 8 & 1 & 12.50 & BHAMNR \\
\hline 40 & Portable tire inflator & 2 & 16 & 2 & 12.50 & BHAMNR \\
\hline 41 & Weld master vulcanizer & 1 & 8 & 1 & 12.50 & BHAMNR \\
\hline 42 & Airline gauge & 2 & 16 & 2 & 12.50 & BHAMNR \\
\hline 43 & $\begin{array}{l}\text { Steam cleaner (complete) oil-fired or } \\
\text { electric }\end{array}$ & 1 & 8 & 0 & 0 & NA \\
\hline 44 & High-pressure washer & 1 & 8 & 1 & 12.50 & BHAMNR \\
\hline 45 & Tire changer complete with bead breaker & 1 & 8 & 0 & 0 & NA \\
\hline 46 & Various sizes of wheel braces & 3 sets & 24 sets & 8sets & 33.33 & BHAMNR \\
\hline 47 & $\begin{array}{l}\text { Tyre repair kit comprising rasp, scissors, } \\
\text { tire knife, sticher, wire brush, etc }\end{array}$ & 2 sets & 16 sets & 2 & 12.50 & BHAMNR \\
\hline 48 & $\begin{array}{l}\text { Service station set of tool kit plus special } \\
\text { varnishes for removal of oil filter }\end{array}$ & 2 sets & 16 sets & 4 & 25.00 & BHAMNR \\
\hline 49 & Pipe wrench, clamp or vice & 3 sets & 24 sets & 9 & 37.50 & BHAMNR \\
\hline 50 & Wheel alignment gauge & 1 set & 8 sets & 1 & 12.50 & BHAMNR \\
\hline 51 & Flat spanners (long and short) & 2 & 16 & 6 & 37.50 & BHAMNR \\
\hline 52 & Clutch alignment gauge & 5 & 40 & 4 & 10.00 & BHAMNR \\
\hline 53 & Adjustable wrench & 3 & 24 & 8 & 33.33 & BHAMNR \\
\hline 54 & Injector repair machine & 1 & 8 & 1 & 12.50 & BHAMNR \\
\hline 55 & Injector needle service kit & 1 & 8 & 1 & 12.50 & BHAMNR \\
\hline 56 & Pullers, different sizes & 3 & 24 & 4 & 16.67 & BHAMNR \\
\hline 57 & Spark plug tester & 4 & 32 & 2 & 6.25 & BHAMNR \\
\hline 58 & Workbench with vices & 2 & 16 & 9 & 56.25 & BHAMNR \\
\hline \multirow[t]{3}{*}{59} & Portable engine hoist & 2 & 16 & 3 & 18.75 & BHAMNR \\
\hline & GENERAL/SERVICE AND & & & & & BHAMNR \\
\hline & RECONDITIONING & & & & & \\
\hline 60 & $\begin{array}{l}\text { Diesel engine phasing and calibration } \\
\text { machine }\end{array}$ & 1 & 8 & 0 & 0 & NA \\
\hline 61 & Electrical test bench & 1 & 8 & 0 & 0 & NA \\
\hline 62 & $\begin{array}{l}\text { Cylinder boring machine with accessories } \\
\text { and assorted tools }\end{array}$ & 1 & 8 & 0 & 0 & NA \\
\hline 63 & $\begin{array}{l}\text { Honing machine with accessories and } \\
\text { assorted cutters }\end{array}$ & 1 & 8 & 0 & 0 & NA \\
\hline 64 & Bottle jack (hydraulic) light and heavy & 1 & 8 & 2 & 25.00 & BHAMNR \\
\hline 65 & Vehicle tire & 2 each & 16 each & 6 & 37.50 & BHAMNR \\
\hline 66 & Trolley jacks & 2 & 16 & 2 & 12.50 & BHAMNR \\
\hline 67 & Motor scope (engine analyzer) & 2 & 16 & 1 & 6.25 & BHAMNR \\
\hline 68 & $\begin{array}{l}\text { Auto Electrical system instructional } \\
\text { chassis }\end{array}$ & 1 & 8 & 0 & 0 & NA \\
\hline 69 & Armature growler & 1 & 8 & 0 & 0 & NA \\
\hline 70 & Hydraulic nipple forming tool & 1 & 8 & 0 & 0 & NA \\
\hline
\end{tabular}




\begin{tabular}{|c|c|c|c|c|c|c|}
\hline 71 & Timing light & 1 & 8 & 1 & 12.50 & BHAMNR \\
\hline 72 & Inspection pits & 2 & 16 & 6 & 37.50 & BHAMNR \\
\hline 73 & Compression gauge & 2 & 16 & 3 & 18.75 & BHAMNR \\
\hline 74 & Valve spring compression kit & 2 & 16 & 2 & 25.50 & BHAMNR \\
\hline 75 & Coil spring compressor (for suspension) & 2 & 16 & 0 & 0 & NA \\
\hline 76 & Torgue wrench pre-set type & 2 & 16 & 5 & 31.25 & BHAMNR \\
\hline 77 & Torque wrench dial type & 2 & 16 & 3 & 18.75 & BHAMNR \\
\hline 78 & Carburetor service kit & 2 & 16 & 1 & 6.25 & BHAMNR \\
\hline 79 & Piston ring compressor & 2 & 16 & 4 & 25.00 & BHAMNR \\
\hline 80 & Axle stands & 8 & 64 & 24 & 37.75 & BHAMNR \\
\hline 81 & $\begin{array}{l}\text { Diagnostic testing machine (exhaust gas } \\
\text { analyzer) }\end{array}$ & 1 & 8 & 1 & 12.50 & BHAMNR \\
\hline & OTHER UTILITIES & & & & & BHAMNR \\
\hline 82 & Fire extinguisher & 4 & 32 & 2 & 6.25 & BHAMNR \\
\hline 83 & Sand buckets & 4 & 32 & 2 & 6.25 & BHAMNR \\
\hline 84 & Water buckets & 4 & 32 & 21 & 65.63 & A \\
\hline 85 & Hoist and box & 1 & 8 & 1 & 12.50 & BHAMNR \\
\hline 86 & First aid box & 1 & 8 & 2 & 25.50 & BHAMNR \\
\hline 87 & Workshop overalls & $\begin{array}{c}\text { Depending } \\
\text { on no of } \\
\text { staff and } \\
\text { students }\end{array}$ & $\begin{array}{c}\text { Depending } \\
\text { on no of } \\
\text { staff and } \\
\text { students }\end{array}$ & Available & 95.00 & A \\
\hline 88 & Complete vehicle engine (petrol) & 1 & 8 & 5 & 62.50 & A \\
\hline 89 & Complete vehicle engine (diesel) & 1 & 8 & 2 & 25.00 & BHAMNR \\
\hline 90 & Live vehicle & 1 & 8 & 2 & 25.00 & BHAMNR \\
\hline 91 & Camshaft grinding machine & 1 & 8 & 0 & 0 & NA \\
\hline
\end{tabular}

Key: A (50\% and above) = Available, BHAMNR (1\% to 49\%) = Below Half of Average Minimum Number Required, NA $(0 \%)=$ Not Available

The data presented in Table 1 revealed that at the time of collecting data for this study, only 4 items out of the 91 tools and equipment required by NBTE for implementing MVMWC contents in Nigeria's technical colleges were available at $50 \%$ and above in technical colleges in North Central Nigeria based on NBTE minimum Standard. The items were: Workbench with vices, water buckets, workshop overalls, and petrol engines, with $56.25 \%, 65.63 \%, 95 \%$, and $62.50 \%$ respectively. All the other 87 tools and equipment required by NBTE for the implementing the curriculum contents of the MVMWC in technical colleges in the North Central States fall short of $50 \%$ of the minimum standard required by NBTE. 13 items were $0 \%$ that is not available, while 74 items were $(1 \%-49 \%)$ below the average of the minimum number required. FGD also corroborated the lack of instructional facilities in technical colleges from their report.

The data presented in Table 2 revealed that 1 item (workshop overalls) with a mean of 4.75 was used to a very great extent. Some other 4 items (open and flat spanners; Pipe wrench, clamp or vice; Flat spanners long and short; Workbench with vices) with their mean ranged from 3.87 to 4.37 were used to a great extent. Another 25 items were moderately used with their mean range from 2.82 and 3.45. The other 37 items were utilized to a low extent with a mean from 1.55 to 2.47 while 24 items others were utilized to the lowest extent with a mean of 1.00. The grand/overall mean was 2.21 . This shows that the extent of utilization of instructional facilities as revealed by respondents was generally low. FGD as well reported a low extent of the use of instructional facilities in technical colleges. 
Table 2. Mean Ratings and Standard Deviation (SD) of Respondents on the Extent of Utilization of Instructional Facilities in Implementing the MVMWC Contents in Technical Colleges in North Central Nigeria

\begin{tabular}{|c|c|c|c|c|}
\hline SN & $\begin{array}{l}\text { The extent to which Instructional Facilities were } \\
\text { Effectively Utilized in Implementing the MVMWC } \\
\text { Contents }\end{array}$ & Mean & SD & Remarks \\
\hline 1 & $\begin{array}{l}\text { Toolboxes (comprising a set of flat, ring, half-round, } \\
\text { and triangular files) }\end{array}$ & 3.37 & 0.32 & Moderate Extent \\
\hline 2 & Ball pein hammer & 2.12 & 0.32 & Low Extent \\
\hline 3 & Hacksaws with extra blades & 3.00 & 0.49 & Moderate Extent \\
\hline 4 & $\begin{array}{l}300 \mathrm{~mm} \text { engineer rule socket spanners sets, with } \\
\text { extension }\end{array}$ & 3.37 & 0.48 & Moderate Extent \\
\hline 5 & (6-32) open and flat spanners & 3.87 & 0.32 & Great Extent \\
\hline 6 & Ring spanners $(6-32 \mathrm{~mm})$ & 3.43 & 0.35 & Moderate Extent \\
\hline 7 & Energy stone/block cloth & 1.00 & 0.00 & Lowest Extent \\
\hline 8 & Plug spanners & 2.45 & 0.24 & Low Extent \\
\hline 9 & Magnet spanners & 2.12 & 0.29 & Low Extent \\
\hline 10 & Allen keys & 2.11 & 0.00 & Low Extent \\
\hline 11 & Feeler gauges & 2.47 & 0.32 & Low Extent \\
\hline 12 & Oil cans & 3.00 & 0.00 & Moderate Extent \\
\hline 13 & Grease guns & 3.24 & 0.48 & Moderate Extent \\
\hline 14 & Spark plug files & 2.12 & 0.32 & Low Extent \\
\hline 15 & Combination pliers & 3.42 & 0.50 & Moderate Extent \\
\hline 16 & Longnose pliers & 2.87 & 0.32 & Moderate Extent \\
\hline 17 & Wirecutter & 3.27 & 0.48 & Moderate Extent \\
\hline 18 & Tyre pressure gauges & 2.12 & 0.32 & Low Extent \\
\hline & DRILLING AND SCREW CUTTING & & & \\
\hline 19 & Electric Hand Drill & 2.87 & 0.32 & Moderate Extent \\
\hline 20 & Drill bits & 3.27 & 0.34 & Moderate Extent \\
\hline 21 & Set of stock and dies - UNC, UNF, and metric & 2.00 & 0.00 & Low Extent \\
\hline 22 & Taps and wrenches - UNC, UNF, and metric & 2.00 & 0.00 & Low Extent \\
\hline 23 & Thread file & 2.12 & 0.23 & Lowest Extent \\
\hline 24 & Roller type thread restorer & 1.64 & 0.21 & Lowest Extent \\
\hline 25 & $\begin{array}{l}\text { Screw (stud) extractor set } \\
\text { MEASURING TOOLS }\end{array}$ & 1.00 & 0.00 & Lowest Extent \\
\hline 26 & Vernier caliper with clock & 2.87 & 0.32 & Moderate Extent \\
\hline 27 & Hand gloves/apron & 2.82 & 0.50 & Moderate Extent \\
\hline 28 & Surface plates & 3.41 & 0.43 & Moderate Extent \\
\hline 29 & Vee blocks & 2.00 & 0.00 & Low Extent \\
\hline 30 & $\begin{array}{l}\text { Micrometer } 0.25 \mathrm{~mm}, 25-50 \mathrm{~mm}, 50-75 \mathrm{~mm} \text { internal } \\
\text { and external }\end{array}$ & 3.34 & 0.45 & Moderate Extent \\
\hline 31 & $\begin{array}{l}\text { Dial gauge indicator with magnetic stand } \\
\text { MACHINE TOOLS }\end{array}$ & 1.00 & 0.00 & Lowest Extent \\
\hline 32 & Grinding machines with assorted wheels & 3.43 & 0.45 & Moderate Extent \\
\hline 33 & A bench grinder with wheels & 2.24 & 0.48 & Low Extent \\
\hline 34 & Workshop surface gauges & 1.74 & 0.24 & Low Extent \\
\hline 35 & $\begin{array}{l}\text { Valve grinding machine } \\
\text { JOINING METALS }\end{array}$ & 1.00 & 0.00 & Lowest Extent \\
\hline 36 & Blow lamps & 2.00 & 0.00 & Low Extent \\
\hline 37 & $\begin{array}{l}\text { Soldering iron } \\
\text { LUBRICATION BAY / TYRE AND WHEEL } \\
\text { SERVICE }\end{array}$ & 2.00 & 0.00 & Low Extent \\
\hline 38 & $\begin{array}{l}\text { Compressor (3phase motor-driven type complete with } \\
\text { a spray gun, grease, hose) }\end{array}$ & 2.00 & 0.00 & Low Extent \\
\hline 39 & Wheel balance (rim 13-15) & 2.00 & 0.00 & Low Extent \\
\hline 40 & Portable tire inflator & 1.72 & 0.15 & Low Extent \\
\hline 41 & Weld master vulcanizer & 2.00 & 0.00 & Low Extent \\
\hline 42 & Airline gauge & 1.00 & 0.00 & Lowest Extent \\
\hline 43 & Steam cleaner (complete) oil-fired or electric & 1.00 & 0.00 & Lowest Extent \\
\hline 44 & High-pressure washer & 1.00 & 0.00 & Lowest Extent \\
\hline 45 & Tire changer complete with bead breaker & 2.00 & 0.32 & Low Extent \\
\hline 46 & Various sizes of wheel braces & 3.12 & 0.32 & Moderate Extent \\
\hline
\end{tabular}




\begin{tabular}{|c|c|c|c|c|}
\hline 47 & $\begin{array}{l}\text { Tyre repair kit comprising rasp, scissors, tire knife, } \\
\text { sticher, wire brush, etc }\end{array}$ & 1.71 & 0.26 & Low Extent \\
\hline 48 & $\begin{array}{l}\text { Service station set of tool kit plus special varnishes for } \\
\text { removal of oil filter }\end{array}$ & 1.62 & 0.48 & Low Extent \\
\hline 49 & Pipe wrench, clamp or vice & 4.00 & 0.00 & Great Extent \\
\hline 50 & Wheel alignment gauge & 2.37 & 0.48 & Low Extent \\
\hline 51 & Flat spanners (long and short) & 4.32 & 0.50 & Great Extent \\
\hline 52 & Clutch alignment gauge & 1.00 & 0.00 & Lowest Extent \\
\hline 53 & Adjustable wrench & 3.00 & 0.00 & Moderate Extent \\
\hline 54 & Injector repair machine & 1.00 & 0.00 & Lowest Extent \\
\hline 55 & Injector needle service kit & 2.00 & 0.00 & Low Extent \\
\hline 56 & Pullers, different sizes & 2.00 & 0.00 & Low Extent \\
\hline 57 & Spark plug tester & 1.62 & 0.48 & Low Extent \\
\hline 58 & Workbench with vices & 4.37 & 0.48 & Great Extent \\
\hline \multirow[t]{2}{*}{59} & Portable engine hoist & 1.00 & 0.00 & Lowest Extent \\
\hline & GENERAL / SERVICE AND RECONDITIONING & & & \\
\hline 60 & Diesel engine phasing and calibration machine & 1.00 & 0.00 & Lowest Extent \\
\hline 61 & Electrical test bench & 1.00 & 0.00 & Lowest Extent \\
\hline 62 & $\begin{array}{l}\text { Cylinder boring machine with accessories and } \\
\text { assorted tools }\end{array}$ & 1.00 & 0.00 & Lowest Extent \\
\hline 63 & Honing machine with accessories and assorted cutters & 1.00 & 0.00 & Lowest Extent \\
\hline 64 & Bottle jack (hydraulic) light and heavy & 2.37 & 0.48 & Low Extent \\
\hline 65 & Vehicle tire & 2.00 & 0.00 & Low Extent \\
\hline 66 & Trolley jacks & 2.00 & 0.00 & Low Extent \\
\hline 67 & Motor scope (engine analyzer) & 1.00 & 0.00 & Lowest Extent \\
\hline 68 & Auto Electrical system instructional chassis & 1.00 & 0.00 & Lowest Extent \\
\hline 69 & Armature growler & 1.00 & 0.00 & Lowest Extent \\
\hline 70 & Hydraulic nipple forming tool & 1.00 & 0.00 & Lowest Extent \\
\hline 71 & Timing light & 2.00 & 0.00 & Low Extent \\
\hline 72 & Inspection pits & 2.85 & 0.43 & Moderate Extent \\
\hline 73 & Compression gauge & 1.55 & 0.13 & Low Extent \\
\hline 74 & Valve spring compression kit & 1.00 & 0.00 & Lowest Extent \\
\hline 75 & Coil spring compressor (for suspension) & 1.00 & 0.00 & Lowest Extent \\
\hline 76 & Torgue wrench pre-set type & 3.21 & 0.53 & Moderate Extent \\
\hline 77 & Torque wrench dial type & 2.22 & 0.43 & Low Extent \\
\hline 78 & Carburetor service kit & 2.00 & 0.00 & Low Extent \\
\hline 79 & Piston ring compressor & 3.12 & 0.32 & Moderate Extent \\
\hline 80 & Axle stands & 3.12 & 0.45 & Moderate Extent \\
\hline 81 & $\begin{array}{l}\text { Diagnostic testing machine (exhaust gas analyzer) } \\
\text { OTHER UTILITIES }\end{array}$ & 1.45 & 0.12 & Lowest Extent \\
\hline 82 & Fire extinguisher & 2.11 & 0.30 & Low Extent \\
\hline 83 & Sand buckets & 2.12 & 0.32 & Low Extent \\
\hline 84 & Water buckets & 3.44 & 0.00 & Moderate Extent \\
\hline 85 & Hoist and box & 1.00 & 0.00 & Lowest Extent \\
\hline 86 & First aid box & 1.00 & 0.00 & Lowest Extent \\
\hline 87 & Workshop overalls & 4.75 & 0.32 & $\begin{array}{l}\text { Very Great } \\
\text { Extent }\end{array}$ \\
\hline 88 & Complete vehicle engine (petrol) & 3.45 & 0.00 & Moderate Extent \\
\hline 89 & Complete vehicle engine (diesel) & 2.00 & 0.00 & Low Extent \\
\hline 90 & Live vehicle & 2.84 & 0.34 & Moderate Extent \\
\hline \multirow[t]{2}{*}{91} & Camshaft grinding machine & 1.00 & 0.00 & Lowest Extent \\
\hline & Grand/Overall & 2.21 & 0.14 & Low Extent \\
\hline
\end{tabular}

The data presented in Table 1 provided answers to research question number 1 which is on the instructional facilities available for implementing the curriculum contents of the MVMWC in technical colleges in the North Central States of Nigeria. Findings revealed that only four items out of the 91 tools and equipment required by NBTE for implementing MVMWC contents in Nigeria's technical colleges were available at $50 \%$ and above in technical colleges in the North Central States 
of Nigeria based on NBTE minimum standard. The items were: Workbench with vices, water buckets, workshop overalls, and petrol engines, with $56.25 \%, 65.63 \%, 95 \%$, and $62.50 \%$ respectively. All the other 87 tools and equipment required by NBTE for implementing the curriculum contents of the MVMWC in technical colleges in the North Central States fall short of $50 \%$ of the minimum standard required by NBTE. 13 out of the 87 tools and equipment not available were absent with $0 \%$ recorded. FGD also corroborated the lack of instructional facilities in technical colleges from their report. Findings revealed that there is a dearth of instructional facilities in the technical colleges in the North Central States of Nigeria. This finding is in line with the views of Ofoha et al. [13] and Omosewo, \& Akanmu [14] who stated that schools lack basic instructional facilities necessary for effective curriculum implementation. Most of the equipment, tools, and workshop facilities in the technical colleges are either broken down, damaged, or dilapidated and they are not replaced or renovated [22]. Abassah [23] stated that instructional materials and consumables in technical colleges are very expensive and the federal and state governments have not been providing funds to address this critical area. The government, according to Abassah, is giving just lip service to technical education.

Table 2 presented an answer to research question 2 which is on the extent of utilization of instructional facilities in implementing the curriculum contents of the MVMWC in technical colleges in the North Central States of Nigeria. Findings revealed that only 1 item (workshop overalls) was used to a very great extent while 4 other items were used to a great extent. Another 25 items were moderately used while 29 items were utilized to a low extent and 32 items were utilized to the lowest extent; owing to unavailability. This shows that the extent of utilization of the very few instructional facilities that are available in implementing the curriculum contents of the MVMWC in technical colleges in the North Central States is generally low. FGD as well reported a low extent of the use of instructional facilities in technical colleges. This could be attributed to the high scarcity of the facilities which adversely affected the utilization of the very few available ones; especially as some of the few available facilities could not be used in isolation. Furthermore, even some of the very few available facilities are broken down, damaged, or dilapidated; hence, their utilization impossible.

\section{CONCLUSION}

The findings of this study revealed: lack of basic instructional facilities for effective implementation of the MVMWC in technical colleges in the North Central States of Nigeria; and a low extent of utilization of the very few insignificant numbers of instructional facilities available. Therefore, unless affirmative action is taken to remedy above established factors, by all stakeholders of the MVMWC implementation in the North Central States of Nigeria, technical college graduates will continue to graduate without the relevant knowledge, attitude, and skills required for a successful career in the MVMW vocation; making them irrelevant and almost useless in the automobile industry, and finding it difficult to gain employment or even establish self-owned automobile enterprises. The government should provide basic instructional facilities for the implementation of MVMWC in all the technical colleges in North Central Nigeria. The instructional facilities for the implementation of MVMWC in all the 
technical colleges in North Central Nigeria should be effectively utilized when made available. Based on the findings of this study, it was concluded that, for graduates of the MVMW program in technical colleges in North-Central Nigeria to acquire the relevant knowledge, attitude, and skills required for gainful employment and be successful in the MVMW vocation, all hands must be on deck by all MVMWC implementation stakeholders to salvage the situation through: provision of basic instructional facilities; as well as effective utilization of the available instructional facilities by teachers and instructors.

\section{REFERENCES}

[1] R. Malone, "Wisconsin Natural Resources Magazine," Wisconsin Natural Resources Magazine, 2006.

[2] New York State Automobile Dealers Association (NYSADA), Auto Jobs. New York State Automobile Dealers Association (NYSADA), 2006.

[3] A. E. Schwaller, Motor Automotive Technology. USA: Delmar Publisher, 1993.

[4] Certified Master Tech, "Modern Automotive Electronics, Modern Transportation Technology," Certified Master Tech, 2009.

[5] AutoMech, "Today's Car is A Rolling Computer, Automech: Introduction to Controls in Automotive Mechatronics," AutoMech, 2012.

[6] United States Bureau of Labour Statistics (USBLS), "Auto Mechanics Need High-Tech Skills," 2012.

[7] R. Audu, A. H. Musta'amal, M. S. S. B. Yusri, and M. M. Inti, "Retraining Needs of Motor Vehicle Mechanics Teachers," J. Tech. Educ. Train., vol. 6, no. 1, pp. 1-11, 2014.

[8] O. J. Nzekwe, "The Impact of the Implementation of the Nigerian Curriculum Initiatives on Secondary
School Administrators and Teachers in Enugu State," University of Calgary, 2013.

[9] O. A. Lawanson and N. T. Gede, "Provision and Management of School Facilities for the Implementation of UBE Programme," J. Educ. Soc. Res., vol. 1, no. 4, pp. 47-55, 2011.

[10] L. O. Anike and T. G. N., "Provision and Management of School Facilities for the Implementation of Ube Programme," J. Educ. Soc. Res., vol. 1, no. 4, pp. 47-55, 2011.

[11] Nigerian Educational Research and Development Council (NERDC), "Motor Vehicle Mechanics, Senior Secondary School Curriculum," 2009.

[12] National Board for Technical Education (NBTE), Guidelines and Procedures for the Establishment of Private Technical and Technological Institutions in Nigeria. National Board for Technical Education (NBTE), 2014.

[13] D. Ofoha, C. N. Uchegbu, B. Anyikwa, and N. Micheal, A Critical Appraisal of the Mode of Implementation of Nigerian Secondary School Curriculum: Towards Socio-Economic Empowerment of Youth. ernwaca, 2009.

[14] O. E. Omosewo and M. A. Akanmu, Evolution of Functional Basic and Senior Secondary Education Curriculum in Nigeria: Implications for Effective Implementation. IISTE, 2013.

[15] O. S. Okobiah, "The Educational Imbalance between the Northern and Southern States of Nigeria: A ReDirection of Educational Policies," Nairametrics, 2002.

[16] C. G. Nyapson, "Skill Improvement Needs of Self-Employed Technical College Motor Vehicle Mechanic Graduates in Plateau State," University of Nigeria, Nsukka, 2015.

[17] O. F. Jika, "Effect Guided Discovery 
Method of Instruction on Students' Performance on Auto Mechanics in Technical Colleges in Benue State," 2010.

[18] M. A. Odigiri and E. O. Ede, "Integration of New Technological Innovations in Automobiles into the Curriculum for Nigerian Technical College Programmes," Int. J. Vocat. Tech. Educ., vol. 2, no. 5, pp. 89-94, 2010.

[19] A. M. Idris, "Effect of Cognitive Apprenticeship Instructional Method on Auto-Mechanics Students," AUJT, vol. 16, no. 2, pp. 89-98, 2012.

[20] M. M. Inti, A. B. A. Latib, and A. Rufai, "An Appraisal of Technical Skills Possessed by Technical College Auto-Mechanics Graduates in Nigeria," IISTE, 2014.

[21] K. C. Udogu, "Emerging Technology Skills Required by Technical College Graduates of Motor Vehicle Mechanic's Work (MVMW) in Establishing Automobile Enterprises in Anambra and Enugu States of Nigeria," 2015.
[22] G. U. Nwiyi and F. S. Okorie, "Problems Militating Against Curriculum Implementation on Vocational/Technical Subject in Secondary Schools in Nigeria," African Educ. Indices, vol. 7, no. 1, pp. 7-12, 2014.

[23] M. Abassah, "Analysis of the Problems and Prospect of the Technical College Teachers in Nigeria," in Proceedings of the 2011 International Conference on Teaching, Learning and Change, International Association for Teaching and Learning (IATEL), 2011, pp. $697-703$. 